University of Nebraska - Lincoln

DigitalCommons@University of Nebraska - Lincoln

\title{
Impact of West Nile Virus and Other Mortality Factors on American White Pelicans at Breeding Colonies in the Northern Plains of North America
}

\author{
Marsha A. Sovada \\ USGS Northern Prairie Wildlife Research Center, msovada@usgs.gov \\ Pamela J. Pietz \\ USGS Northern Prairie Wildlife Research Center, ppietz@usgs.gov \\ Kathryn A. Converse \\ USGS Northern Prairie Wildlife Research Center \\ D. Tommy King \\ National Wildlife Research Center, US Department of Agriculture, tommy.king@aphis.usda.gov \\ Erik K. Hofmeister \\ National Wildlife Health Center, US Geological Survey \\ See next page for additional authors \\ Follow this and additional works at: https://digitalcommons.unl.edu/usgsnpwrc \\ Part of the Other International and Area Studies Commons
}

Sovada, Marsha A.; Pietz, Pamela J.; Converse, Kathryn A.; King, D. Tommy; Hofmeister, Erik K.; Scherr, Paulette; and Ip, Hon S., "Impact of West Nile Virus and Other Mortality Factors on American White Pelicans at Breeding Colonies in the Northern Plains of North America" (2008). USGS Northern Prairie Wildlife Research Center. 130.

https://digitalcommons.unl.edu/usgsnpwrc/130

This Article is brought to you for free and open access by the US Geological Survey at DigitalCommons@University of Nebraska - Lincoln. It has been accepted for inclusion in USGS Northern Prairie Wildlife Research Center by an authorized administrator of DigitalCommons@University of Nebraska - Lincoln. 


\section{Authors}

Marsha A. Sovada, Pamela J. Pietz, Kathryn A. Converse, D. Tommy King, Erik K. Hofmeister, Paulette Scherr, and Hon S. Ip 


\title{
Impact of West Nile virus and other mortality factors on American white pelicans at breeding colonies in the northern plains of North America
}

\author{
Marsha A. Sovada ${ }^{a, *}$, Pamela J. Pietz ${ }^{a}$, Kathryn A. Converse ${ }^{b}$, D. Tommy King ${ }^{c}$, \\ Erik K. Hofmeister ${ }^{b}$, Paulette Scherr ${ }^{d}$, Hon S. Ip ${ }^{b}$ \\ ${ }^{a}$ Northern Prairie Wildlife Research Center, US Geological Survey, 8711 37th Street SE, Jamestown, ND 58401, USA \\ ${ }^{b}$ National Wildlife Health Center, US Geological Survey, 6006 Schroeder Road, Madison, WI 53711, USA \\ ${ }^{c}$ National Wildlife Research Center, US Department of Agriculture, P.O. Box 6099, Mississippi State University, MS 39762, USA \\ ${ }^{\mathrm{d}}$ Arrowwood National Wildlife Refuge, US Fish and Wildlife Service, 7745 11th Street SE, Pingree, ND 58476, USA
}

\section{A R T I C L E I N F O}

\section{Article history:}

Received 4 October 2007

Received in revised form

17 January 2008

Accepted 21 January 2008

Available online 21 March 2008

Keywords:

American white pelican

Late breeding season mortality

Mortality factors

Pelecanus erythrorhynchos

West Nile virus

\begin{abstract}
A B S T R A C T
American white pelicans (Pelecanus erythrorhynchos) are colonial-nesting birds and their breeding sites are concentrated in a few small areas, making this species especially vulnerable to factors that can influence productivity, such as disease, disturbance, predation, weather events and loss of nesting habitat. Nearly half of the American white pelican population breeds at four colonies in the northern plains: Chase Lake National Wildlife Refuge (NWR) in North Dakota, Bitter Lake (Waubay NWR) in South Dakota, Medicine Lake NWR in Montana, and Marsh Lake in Minnesota. Thus, sustained productivity at these colonies is crucial to the health of the entire species. During the latter half of the 2002 and 2003 breeding seasons, unusually high mortality of pelican chicks was observed at these colonies. West Nile virus (WNv) was identified as one source of these losses. In 2004-2007 we monitored three major colonies in the northern plains to assess mortality of chicks during the late breeding season. We documented severe weather events, disturbance, and WNv as factors contributing to chick mortality. Before WNv arrived in the region in 2002, chick mortality after mid-July was $\leqslant 4 \%$, and then jumped to as high as $44 \%$ in the years since WNv arrived. WNv kills older chicks that are no longer vulnerable to other common mortality factors (e.g., severe weather, gull predation) and typically would have survived to fledge; thus WNv appears to be an additive mortality factor. Persistence of lower productivity at American white pelican colonies in the northern plains might reduce the adult breeding population of this species in the region.
\end{abstract}

Published by Elsevier Ltd.

\section{Introduction}

American white pelicans (Pelecanus erythrorhynchos) are colonial breeders; consequently they are especially vulnerable to multiple factors (e.g., diseases, weather events, loss of nesting habitats, predation, and disturbances [human or otherwise]) that can influence productivity. Furthermore, nearly half of the population breeds at four major colonies in the northern

\footnotetext{
* Corresponding author: Tel.: +1 1701253 5506; fax: +1 17012535553.

E-mail addresses: MSovada@usgs.gov (M.A. Sovada), PPietz@usgs.gov (P.J. Pietz), kconverse@usgs.gov (K.A. Converse), Tommy. King@aphis.usda.gov (D. Tommy King), EHoffmeister@usgs.gov (E.K. Hofmeister), Paulette_Scherr@fws.gov (P. Scherr), Hip@usgs.gov (H.S. Ip).
} 
plains: Chase Lake in central North Dakota, Bitter Lake in northeastern South Dakota, Medicine Lake in northeastern Montana, and Marsh Lake in west-central Minnesota (King and Anderson, 2005). Sustained productivity at these colonies is crucial to the health of the entire population.

Deleterious effects of emerging infectious diseases have been observed in populations of threatened and declining wildlife species (Daszak et al., 2000; van Riper et al., 1986; Naugle et al., 2004) and pose significant management challenges. Although white pelicans are not considered a sensitive species, the potential impact of a chronic disease could be devastating to the population because they concentrate in a few major nesting colonies during the breeding season. Concerns about disease were realized in 2002 and 2003 when unusually large numbers of near-fledging American white pelicans died at the four major breeding colonies in the northern plains. Because West Nile virus (WNv) had just arrived in the region (Ginsberg, 2003), this disease was suspected. A few chicks from each colony were tested in 2003 for a suite of diseases; most of these chicks were infected with WNv. Concerns about the long-term impact of $\mathrm{WNv}$ on the population prompted closer monitoring of the breeding colonies in the region. In 2004, we initiated efforts to (1) estimate chick mortality rates for the late breeding season (i.e., post-WNv onset) using data from both pre- and post-WNv years to help determine if the virus was a source of additive mortality; (2) estimate the onset, intensity, and duration of the WNv outbreak in pelican chicks each year; (3) assess the relationship between prevalence of the mosquito population and rate of pelican mortality; and (4) detect secondary disease factors and examine their relationship to $\mathrm{WNv}$ and their relative importance as mortality factors. Finally, to put the impacts of WNv into perspective, we monitored other non-disease factors that affected pelican reproductive success at these colonies.

\section{Study areas and methods}

We conducted the study at three major colony sites in the northern plains: Chase Lake, Bitter Lake, and Medicine Lake (Fig. 1). Chase Lake National Wildlife Refuge (NWR) is $19 \mathrm{~km}$ northwest of Medina in Stutsman County, North Dakota $\left(47^{\circ} 01^{\prime} \mathrm{N}, 99^{\circ} 27^{\prime} \mathrm{W}\right)$. The 1775 -ha refuge is within the previously glaciated Missouri Coteau physiographic region (Bluemle, 1991), characterized by morainic gently rolling plains interspersed with closed wetlands, prairie pastures, planted grasslands, hayfields, and cropland. An additional 2474 ha of federal- and state-owned grasslands and wetlands are adjacent to the refuge. Chase Lake is a shallow, 830-ha alkaline lake that has no outlet and supports no aquatic vertebrates in most years. During the study, pelicans nested on 1-3 islands and, through 2004, pelicans also nested on a peninsula (see Sovada et al., 2005 for additional description). The average number of nests initiated was 13,900 per year (20042006). Breeding by pelicans at Chase Lake National Wildlife Refuge was first documented in 1905 and the colony has been active since then. The area was designated as a National Wildlife Refuge in 1908 to protect the colony.

Bitter Lake is located $5 \mathrm{~km}$ south of Waubay in Day County, South Dakota $\left(45^{\circ} 16^{\prime} \mathrm{N}, 97^{\circ} 19^{\prime} \mathrm{W}\right)$. The 4450 -ha lake is bordered

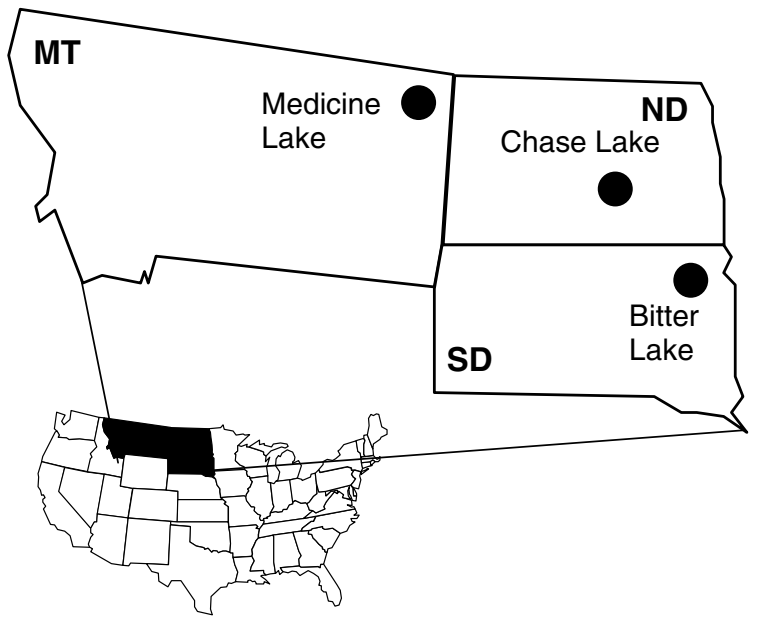

Fig. 1 - Map showing locations of the three studied populations of American white pelicans in the northern plains of the United States: Medicine Lake, MT; Chase Lake, ND; and Bitter Lake, SD.

by a $9.6-\mathrm{km}^{2}$ state game management area on the east and west sides and by private land on the north and south. Bitter Lake is located in the Prairie Coteau of northeastern South Dakota, which is a landscape of rolling tallgrass prairie hills, interspersed with thousands of small wetlands and lakes. Flat areas are tilled for small grains, corn, sunflowers, and alfalfa (Medicago sativa) or used for pasture. The lake contains many islands created when rising water surrounded hilltops; pelicans nest on four of these islands. Historically there were five colonies at other lakes in the surrounding area; Bitter Lake has had an active colony since 1987 and was the only active colony in the immediate area during this study (USFWS, Waubay NWR records). During the study, pelicans nested on 3-5 islands, initiating an average of 12,948 nests per year (20042006).

Medicine Lake NWR is located $32 \mathrm{~km}$ south of the community of Medicine Lake in Sheridan County, Montana $\left(48^{\circ} 27^{\prime} \mathrm{N}\right.$, $\left.-104^{\circ} 23^{\prime} \mathrm{W}\right)$. The refuge was established in 1935 and is located on the rolling plains of the Missouri Coteau. Medicine Lake is a large (3320-ha), shallow brackish lake; it is the largest natural lake in eastern Montana (see Madden and Restani, 2005 for additional description). Pelicans nest on two sites within this lake - an island and a peninsula, initiating an average of 3909 nests per year (2004-2006).

Both Chase Lake and Medicine Lake NWRs include designated Wilderness Areas (Wilderness Act of 1964, Section 4c) and, as such, motorized access to nesting islands was restricted. Because these are large lakes, at times severe winds or thunderstorms prevented access to the colonies by researchers.

The climate at all sites is continental, with cold winters, hot summers, and peak rainfall during the early to mid-growing season. Weather is variable and often extreme, with periodic drought, severe hailstorms, great fluctuations in temperature, and frequent strong winds. Weather data from the nearest National Weather Service stations were obtained for the study sites: Robinson, North Dakota, $27 \mathrm{~km}$ northwest of Chase Lake; Waubay National Wildlife Refuge, South Dako- 
ta, $14 \mathrm{~km}$ north of Bitter Lake; and Plentywood, Montana, $37 \mathrm{~km}$ northwest of Medicine Lake NWR.

\subsection{Monitoring colony status}

In 2003, the sudden increase in mortality of chicks during mid-July was conspicuous, with many young birds showing signs of illness with neurologic symptoms of WNv. Beginning in June of each year (2004-2007), we monitored pelican colonies weekly from vantage points that minimized disturbance to nesting birds. Each week, we estimated ratios of healthy/ sick chicks and number of dead chicks to detect the onset of any disease event. We collected information on the environmental conditions and behavior of the sick chicks to help identify the causes of mortalities. In 2004 and 2005, once clinical signs of a disease were detected, our weekly goal was to collect a minimum of 10 moribund or recently dead (no sign of autolysis) chicks at each colony. Individual chicks were collected from throughout each colony to ensure a representative sample. Moribund chicks (staggering, unable to stand or hold up head) were included in the sample because it was difficult to find enough dead chicks that were fresh enough for diagnostic examination. We euthanized moribund chicks by cervical dislocation (Andrews et al., 1993; Gaunt and Oring, 1997; National Wildlife Health Center ACUC guidelines). Prior to euthanizing sick chicks, we collected a blood sample for WNv serology. Chick carcasses and blood samples were kept chilled on ice in coolers and shipped to the US Geological Survey's National Wildlife Health Center (NWHC) in Madison, Wisconsin, for diagnostic examination within $24 \mathrm{~h}$ of collection. If overnight shipping was not possible, carcasses were frozen and shipped as soon as possible.

In 2006, we discontinued intensive collection of carcasses, reducing our collections to three carcasses within 2 weeks of initially observing clinical signs of illness. Our objective was to document the cause of the disease event and the approximate timing (i.e., date) of its onset. We collected another three chicks about 4 weeks later to confirm that continued mortalities were still caused by WNv. In 2007, three carcasses were again collected from Chase Lake and Bitter Lake colonies near the beginning of the WNv outbreak. Chicks collected in 2006 and 2007 did not undergo diagnostics beyond examination for WNv and thus are not included in compilation of diagnostic results below.

\subsection{Diagnostic evaluations}

Suitable chick carcasses underwent complete diagnostic examinations including necropsy, laboratory analyses, and microscopic examination of selected tissues. All birds were kept chilled in a walk-in cooler until they were examined. If frozen, chicks were slowly thawed within a refrigerated room to minimize cell damage. Carcasses that were badly autolyzed and contained mature maggots were considered unsuitable for complete diagnostics and only feather pulp was collected for WNv testing. The chicks were weighed, and then a complete external examination was done. Fractures or other trauma, the level of parasitism, and any other abnormalities were noted. An internal examination was done and the postmortem condition, overall body condition, sex, level of heart changes, and any other unexpected findings were recorded. The postmortem condition was ranked as excellent (fresh), good, fair, or poor (very decomposed), based on the level of tissue decomposition and presence of insect activity. General body condition of each examined chick was ranked as excellent, good, fair, or poor based on visible fat in the coronary groove, intestinal mesentery and abdominal subcutis (Kuiken et al., 1999), its age, and stage of muscle development. Condition of the heart was ranked as normal-no visible abnormality in the size of the heart, tissues appear healthy, pericardial sac clear; mild-no visible abnormality in the size of the heart, one or two small 1-2 mm pale areas in the heart muscle, pericardial sac still clear; moderate-slight increase in the heart size, fluid present in the pericardial sac surrounding the heart with some cloudiness in the pericardial sac, increased number and size of pale areas in the heart muscle; severe-heart enlarged, multiple small to large pale areas in the heart muscle, excess fluid in pericardial sac, pericardial sac cloudy, thickened and often adhering to surrounding tissues. As part of the pathology examination, tissues were tested for $\mathrm{WNv}$, botulinum neurotoxin (BoNT) type C, and Salmonella. Samples were collected for BoNT type $\mathrm{C}$ and Salmonella because these two diseases were previously identified in colonies of nesting white pelicans (NWHC records). During necropsy examinations, the brain, lung, heart, liver, spleen, and kidney were collected in $10 \%$ buffered formalin for microscopic examination; samples of brain, heart, kidney, spleen, feather pulp, and when available, pericardial fluid were collected for WNv tests; heart blood was collected for BoNT type C assay; and liver was collected for Salmonella culture. Virology samples were tested immediately. Botulinum toxin and Salmonella samples from one chick per site in each weekly shipment were submitted immediately for bacteriological tests. All remaining samples for BoNT and Salmonella were archived in an ultra low $\left(-80^{\circ} \mathrm{C}\right)$ freezer. After initial Salmonella tests were completed, additional samples were selected to achieve testing of approximately $50 \%$ of all chicks. Similarly, after initial BoNT samples were processed, additional samples for BoNT assays were selected from chicks that were in good postmortem condition and were not positive for either WNv or Salmonella. Chicks in good postmortem condition (i.e., little decomposition) were used for these assays because postmortem BoNT production or bacterial growth can interfere with the assays (Rocke et al., 1998).

To identify $\mathrm{WNv}$ in tissues, the Real Time Polymerase Chain Reaction (RT-PCR) test was performed on tissues from heart, brain, kidney, and spleen as described by Lanciotti et al. (2000). Not all tissues were tested for every chick; once a positive result was recorded, no additional tissues were tested. Tissues also were examined for viable WNv as follows. For feathers, the vascular pulp was aseptically removed from the feather umbilicus; viral transport media was added to produce a $10 \%$ (wt/volume) solution and homogenized into a suspension (Docherty et al., 2004). The suspension was centrifuged at $800 \times \mathrm{g}$ for $30 \mathrm{~min}$ at $4^{\circ} \mathrm{C}$ and the supernatant added to a Vero cell monolayer in $12-\mathrm{cm}^{2}$ bottles. The cultures were incubated in the $\mathrm{CO}_{2}$ incubator at $37^{\circ} \mathrm{C}$ and $2 \% \mathrm{CO}_{2}$. Samples were examined periodically over 7 days for cytopathic effect. Serum from chicks was tested with WNv antibody blocking ELISA as described by Blitvich et al. (2003). We 
used positive serum attained from WNv-infected chickens as a control. Samples were screened at a dilution of 1:100 and those with a percent inhibition (PI) value greater than or equal to $30 \%$ were considered suspect positive and were confirmed via Plaque-Reduction Neutralization Test (PRNT). Samples with PI values less than $30 \%$ were considered negative for antibodies to WNv (Blitvich et al., 2003). We used standard techniques (Beaty et al., 1989) to conduct PRNT on vero cells at a starting dilution of 1:20 and using a 1999-NY crow isolate of $\mathrm{WNv}$ as the test virus. A $90 \%$ plaque reduction rule was used to determine positive serum samples. Sera found positive for antibody to WNv at 1:20 were further titered in twofold dilutions to determine endpoint titer.

For Salmonella isolation from liver tissues, samples were added to a Rappaport-Vassiliadis (RV) Broth (De Smedt and Bolderdijk, 1987) and incubated at $41.5^{\circ} \mathrm{C}$ for 18 to $24 \mathrm{~h}$. Following incubation, RV cultures were streaked onto Xylose-Lysine-Tergitol 4 Agar (Miller et al., 1991) and Miller Mallinson Agar (Mallinson et al., 2000), and incubated at $37^{\circ} \mathrm{C}$ for 18 $24 \mathrm{~h}$. Suspected colonies were subcultured on Blood Agar Plates for biochemical characterization by the API-20E system (bioMerieux Vitek Inc., Hazelwood, MO). Samples were further screened with polyvalent antisera for Salmonella (Becton Dickinson, Cockeysville, MD) before being serotyped at the US Department of Agriculture, National Veterinary Services Laboratory (Ames, IA).

Clotted heart blood was tested for the presence of BoNT type $C$ with the mouse neutralization assay (Shimizu and Kondo, 1987). Prepared blood samples were injected into pairs (protected and unprotected) of female ICR mice (2-6 weeks old, 15-18 g). We observed the mice 5 days for clinical signs of botulism toxicosis. Paired samples were considered BoNT positive if the protected mouse survived and did not exhibit toxicosis and the unprotected mouse died or exhibited symptoms of toxicosis. If both mice survived and did not exhibit clinical signs of toxicosis, samples were considered BoNT negative.

\subsection{Mortality rates}

We banded chicks at all three colonies in post-WNv years and used available banding records for the years just prior to the arrival of $\mathrm{WNv}$ in the region to estimate pre-fledge mortality rates during the late breeding season. For this study, our goal was to band 2500 pelican chicks at Chase Lake and at least 500 chicks at both Medicine and Bitter lakes each year (2004-2007). Pelican chicks (6-7 weeks old) were banded in late June or early July in each year by placing a US Geological Survey aluminum band on one leg. Fortuitously, our banding efforts within a breeding season occurred just prior to detection of $\mathrm{WNv}$ infections in the colonies (i.e., mid-July). For years prior to this study, banding records were available for colonies at Chase Lake (1999 and 2001-2003) and Medicine Lake (2002 and 2003). No data from pre-WNv years were available for the Bitter Lake colony. We estimated mortality rates by calculating the proportion of bands applied each year that were recovered from dead pre-fledged pelicans in each colony.

Methods of band deployment and retrieval were similar for pre-WNv and post-WNv years. Once or twice per week bands were collected from chicks that had died. At the end of each breeding season, after surviving chicks had fledged, we conducted intensive systematic searches of the nesting sites (islands and peninsulas) to recover any bands from pre-fledged young that died. To eliminate chicks that might have died because of stress or injury caused by banding activities, bands collected within the first week after banding were not included in calculations of mortality rates. Banding activities always occurred $\geqslant 1$ week before the initial WNv deaths were detected.

\subsection{Mosquito monitoring}

The mosquito, Culex tarsalis, has been identified as the major vector of WNv in the region of our study (Marra et al., 2004). Each year, beginning the first week of June and continuing through August, we monitored the presence and relative abundance of mosquitoes at and in the vicinity of the pelican colonies. We collected samples of adult mosquitoes weekly with New Jersey traps (Reinert, 1989). Our trapping was coordinated with a monitoring effort being conducted by the North Dakota Department of Health (see http://www. ndhealth.gov/WNV/Data/Summary.aspx). Many weekly samples from our study areas were too wet to assess species composition. Therefore, we used the North Dakota Department of Health data (average weekly counts) as an index to the prevalence of $C$. tarsalis, through the season. Usable samples at our study areas reflected the statewide trends reported by the North Dakota Department of Health.

\subsection{Data analyses}

Logistic regression models (PROC GENMOD, SAS Institute Inc., 2004) were used to investigate the effect of age, gender, and year on the probability of being diagnosed with WNv. Because WNv first occurs in the colonies when chicks are older, sample sizes of very young chicks were limited; thus we evaluated effects of age from 7 weeks to 11 weeks (approximate fledging age; Knopf and Evans, 2004). A chi-square test was used to compare body condition of birds dying of WNv and other causes. We used PROC MIXED with least square means and contrast statements (SAS Institute Inc., 2004) to evaluate chick mortality rates for the period of mid-July to fledging, comparing pre-WNv and post-WNv years at Chase Lake and Medicine Lake (pre-WNv data were not available for Bitter Lake).

\section{Results}

\subsection{Mortality rates in the late breeding season}

Typically, fewer than five sick or dead adult pelicans were observed at individual colonies in the years before (1999-2001) and after (2002-2006) arrival of WNv (Sovada, pers. obs.). In contrast, a disease event affecting chicks was observed each year at all of the colonies (except Chase Lake 2004 due to colony abandonment) after WNv arrived in the region. Clinical signs of disease in the pelican chicks progressed from head tilt, ataxia, and disorientation to tremors and complete inability to move (Fig. 2). We observed similar onset and progres- 


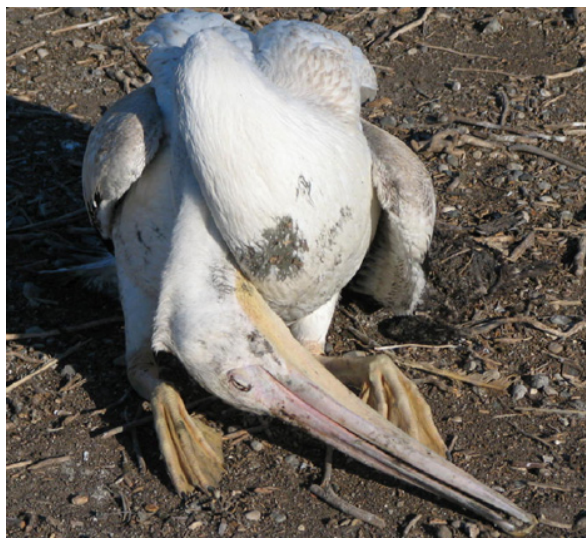

Fig. 2 - American white pelican chick at Chase Lake National Wildlife Refuge in North Dakota showing signs of WNv infection including head tilt, ataxia, and disorientation. Diagnosis of WNv was confirmed for this chick.

sion of disease in the three colonies each of the years that colonies were observed. Observations of diseased chicks first occurred in mid-July, peaked in late-July, and tapered off but continued through August. Eight of nine chicks collected in 2006 and five of six in 2007 tested positive for WNv, confirming the presence of the disease those years (see below for 2004-2005 diagnostic results).

After WNv arrived at pelican colonies in the region (2002 in ND and SD, and 2003 in MT; USGS, National Wildlife Health Center Epizootic data base), we documented chick mortality rates from $8 \%$ to $44 \%$ for the late breeding season and deaths largely were attributed to WNv (Fig. 3). Late breeding season mortality rates for chicks in years prior to arrival of WNv were $\leqslant 4 \%$ and significantly lower than rates in years after the arrival of $\mathrm{WNv}(F=6.72 ; \mathrm{df}=1,12 ; P=0.02)$, although data were sparse for pre-WNv years (see Fig. 3).

\subsection{Disease diagnostics}

We submitted 260 chick carcasses (127 in 2004, 133 in 2005) that were suitable for WNv testing. We did not submit chicks for which evidence suggested severe weather was the cause of death except in the first week of July in 2005 at Chase Lake when severe weather occurred, but we wanted to confirm WNv was not a factor in the mortalities. Although we were unable to determine gender when collecting chicks, postmortem examinations revealed both sexes were well represented with 130 females, 107 males, and 23 unknown. Eight carcasses were too advanced in decomposition for necropsy, but we were able to conduct WNv diagnostic tests on their feather pulp.

Each year at each colony, the first positive WNv culture/ serology was from chicks collected between 13 July and 19 July. Once a positive WNv sample was confirmed at each site, a high frequency (range 74-96\%) of the chicks collected were WNv positive (Table 1, Fig. 4). Of the 208 chicks collected after the disease was detected, 178 (85.6\%) chicks tested positive for WNv and 30 (14.4\%) chicks tested negative. We found no effects of age, sex, year, or their interaction among chicks with $\mathrm{WNv}(P>0.05)$. Among the $30 \mathrm{WNv}$ negative chicks that were collected post-WNv onset, 20 were categorized in poor to fair body condition, seven in good to excellent condition, and three were unsuitable for ranking. No specific etiology was clear for any of these chicks except three tested positive for BoNT type C, two were positive for Salmonella, and three were positive for both BoNT type C and Salmonella.

Among chicks that tested positive for $\mathrm{WNv}, 27 \%$ were considered to be in excellent body condition, $24 \%$ in good condition, $36 \%$ in fair condition, and $13 \%$ in poor condition. Generally, chicks dying from causes other than WNv throughout the breeding season were in poorer body condition than chicks that died from $\mathrm{WNv}\left(\chi^{2}=15.78, \mathrm{df}=3, \mathrm{P}=0.001 ; 5 \%\right.$ excellent condition, $27 \%$ good condition, $53 \%$ fair condition, and $15 \%$ poor condition). This pattern might indicate a

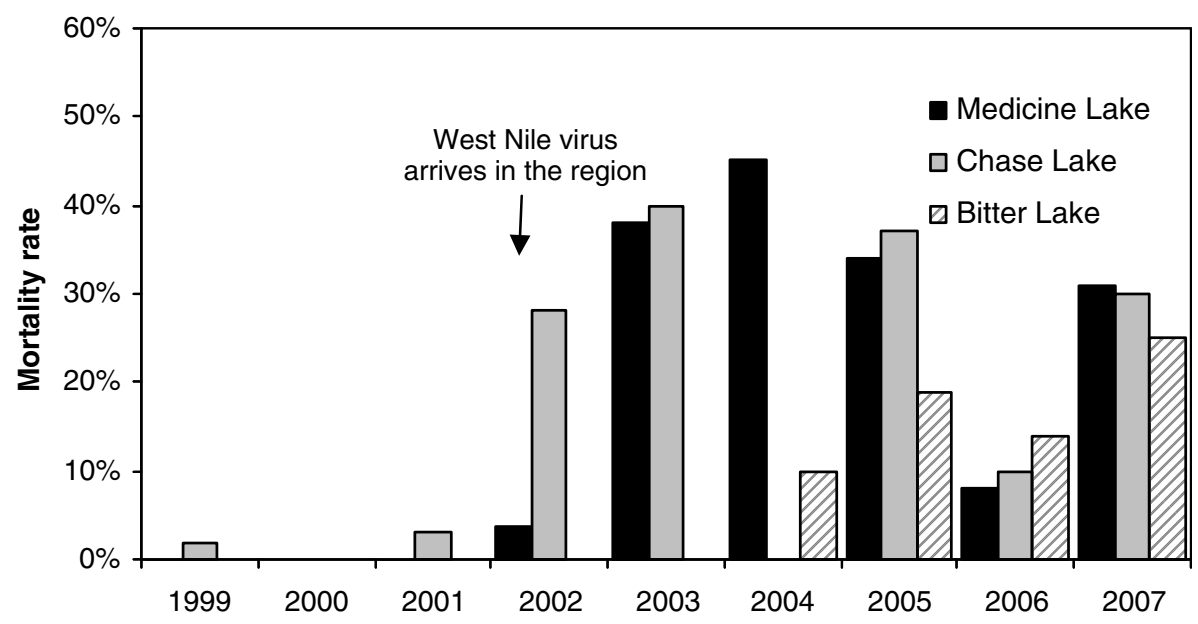

Fig. 3 - Late breeding season (mid-July to fledging) mortality rates of American white pelican chicks from available data collected before and after the arrival of West Nile virus in the northern plains: Chase Lake, ND (1999, 2001-2007); Medicine Lake, MT (2002-2007); Bitter Lake, SD (2004-2007). West Nile virus arrived in the region in 2002. Mortality rates for 2007 illustrate that lower mortality rates in $\mathbf{2 0 0 6}$ did not persist and likely reflected reduced mosquito abundance as a result of drought conditions as shown in Fig. 6. 
Table 1 - Diagnostic results from American white pelican chick carcasses submitted to the National Wildlife Health Center, Madison, Wisconsin, 2004-2005

\begin{tabular}{|c|c|c|c|c|c|}
\hline & \multirow{2}{*}{$\frac{\text { Chase Lake, ND }}{2005}$} & \multicolumn{2}{|c|}{ Bitter Lake, SD } & \multicolumn{2}{|c|}{ Medicine Lake, MT } \\
\hline & & 2004 & 2005 & 2004 & 2005 \\
\hline Number tested & 53 & 60 & 56 & $67^{a}$ & 24 \\
\hline$\% \mathrm{WNv}+$ & 64 & 78 & 91 & 48 & 58 \\
\hline$\% \mathrm{WNv}+$ (post-onset) $^{\mathrm{b}}$ & 83 & 84 & 96 & 74 & 93 \\
\hline $\mathrm{WNv}+/$ tested via serology & $12 / 50$ & $23 / 56$ & $25 / 56$ & $13 / 38$ & $7 / 24$ \\
\hline Salmonella $+/ \mathrm{n}$ & $2 / 17$ & $17 / 30$ & $3 / 16$ & $8 / 29$ & $1 / 14$ \\
\hline Salmonella $+/ \mathrm{n}$ (post-onset) ${ }^{\mathrm{b}}$ & $2 / 11$ & $15 / 27$ & $2 / 13$ & $8 / 18$ & $1 / 9$ \\
\hline BoNT type $C+/ \mathrm{n}$ & $2 / 18$ & $3 / 13$ & $1 / 15^{c}$ & $1 / 14$ & $1 / 14$ \\
\hline BoNT type $C+/ n$ (post-onset) $^{b}$ & $0 / 12$ & $3 / 11$ & $1 / 12^{\mathrm{c}}$ & $0 / 6$ & $1 / 9$ \\
\hline
\end{tabular}

a Eight of the 67 carcasses were unsuitable for diagnostics from necropsy, but WNv test results were obtained on feather pulp.

b Carcasses collected after the onset of WNv in the colony that year.

c One equivocal result not included.
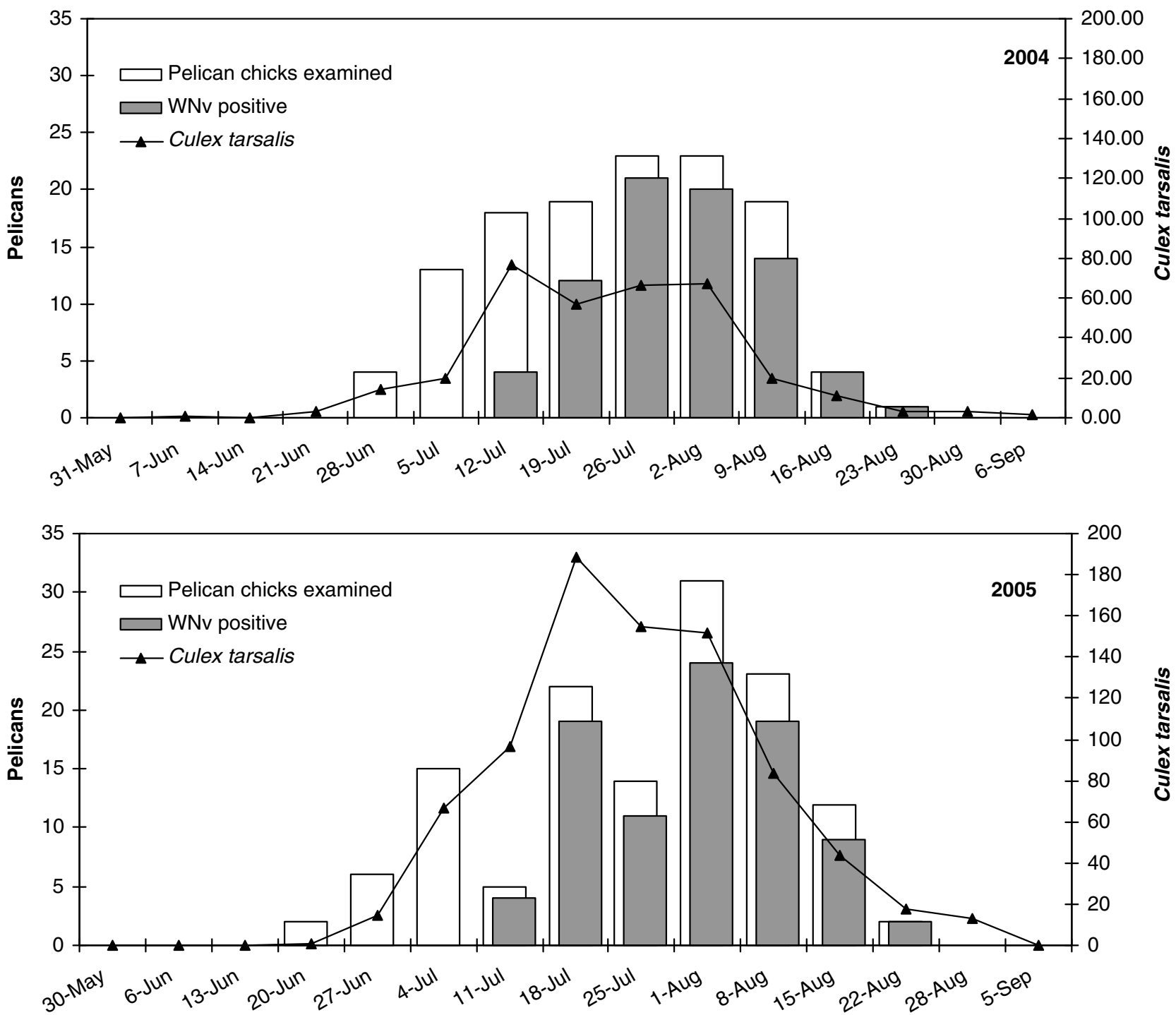

Fig. 4 - Number of American white pelican chick carcasses submitted for diagnostic examination and the number of those chicks that tested positive for West Nile virus during 2004 and 2005. Chicks were submitted from Chase Lake, ND; Medicine Lake, MT; Bitter Lake, SD. Black triangles indicate weekly average number of Culex tarsalis collected by the North Dakota Department of Health (<http://www.ndhealth.gov/WNV/Data/Summary.aspx>). 
shorter course of illness for WNv-infected chicks compared to chicks dying from other causes. The most notable internal conditions observed in chicks with $\mathrm{WNv}$ were gross and microscopic changes (e.g., hemorrhaging) in the heart. Fiftyfour percent of chicks in 2004 and 68\% in 2005 were categorized with mild to severe gross heart changes. Microscopic examination of brain tissues showed chicks with WNv usually had encephalitis or meningoencephalitis, and heart tissues showed a degeneration or loss of muscle fibers.

Each year at each colony there was diagnostic confirmation of some salmonellosis and avian botulism type C. Both diseases are known to occur in pelican chicks (NWHC records). Thirty-one of 106 chicks tested positive for Salmonella, and 8 of 74 chicks tested were positive for BoNT type C (Table 2). Of chicks tested for Salmonella and BoNT that were also positive for WNv $(n=40)$, two had botulism and eight had Salmonella. Of chicks tested for Salmonella and BoNT that did not have WNv $(n=28)$, three had botulism, two had Salmonella, and two had both botulism and Salmonella. Chicks with WNv were not more likely to have botulism $\left(\chi^{2}=2.76, \mathrm{df}=1\right.$, $P=0.094$ ) or Salmonella $\left(\chi^{2}=0.74, \mathrm{df}=1, \mathrm{P}=0.390\right)$.

During necropsy examinations, abnormal tissues in addition to those selected for this study were collected to identify other potential disease conditions. One reason for this was to rule out pathogens or infectious diseases that could infect pelicans, as well as those that could infect field or laboratory personnel. Precautions were taken in handling birds, but examination of abnormal tissues served as an added assurance of safety. Many of the pelican chicks had severe infestations of biting lice resulting in skin, ear, and eye lesions with secondary infections. Other microbial isolates included Acinetobacter baumannii, Aeromonas hydrophila, Aspergilus fumigatus, Bacillus sp., Corynebacteruim sp., Escherichia coli, Myroides sp., Pasteurella multocida, Plesoimonas sp., Proteus sp., Pseudomonas aeruginosa, Staphylococcus spp., Streptococcus sp., and Vibrio sp.

\subsection{Non-disease related mortality events}

In 2004, we observed the complete abandonment of the Chase Lake colony. On 25 May, we discovered that one or more coyotes (Canis latrans) had entered a subcolony of approximately 7000 nests (incubation stage) located on a mainland peninsula, resulting in destruction and abandonment of nests at part of the subcolony early in the breeding season. Coyotes were removed from a nearby den within a week of discovery, but by that time, the mainland subcolony had been completely abandoned by the nesting pelicans. The abandonment progressed over several days, beginning at the mainland end of the peninsula and advancing toward the tip. While adult pelicans were abandoning the peninsula subcolony, activities seemed normal at the north island subcolony (approximately 6000-8000 nests), where most adults were attending chicks. Chicks on the north island were about 2-3 weeks old; the age that chicks start to form small crèches (i.e., groups) to aid in thermoregulation as their parents discontinue brooding them (Lingle, 1977; Evans, 1984). Then, in late May-early June, the entire region (including the three focal colonies) experienced approximately a week-long period of cold (low temperatures: mean $=5.6^{\circ} \mathrm{C}$, range $=1.1-13.3^{\circ} \mathrm{C}$ ), wet (precipitation range $51-81 \mathrm{~mm}$ ), and windy (sustained $\max \sim 40 \mathrm{~km} / \mathrm{h}$, gusts to $65 \mathrm{~km} / \mathrm{h}$ ) weather. Such conditions are likely to kill young, unbrooded chicks. By the time field personnel could access the island on 13 June, only a few live chicks remained and nearly all the adults had abandoned the colony. Many chick carcasses were present, but many were missing and likely had been scavenged by gulls or were assimilated into the environment. The most logical explanation for the demise of the north island subcolony was that most chicks were killed during the storm, and, once the chicks were dead, the adults abandoned the island. We observed similar losses during this severe weather event at the Medicine Lake colony, where approximately 300 nests with young ( $<3$ weeks) chicks failed. Again, we believe the young died from exposure, precipitating the departure of adults.

In 2005, no pelicans nested on the mainland peninsula at Chase Lake. Pelicans selected nesting sites only on islands, initiating nests first on the north island, which had supported a subcolony since 1995, and then the south island, which had a small proportion of nests in 2002-2003 and the majority of nests in 2005 and 2006. By early June 2005, most eggs on the north island had hatched. During a visit to this island on 16 June, we discovered that about half the chicks that had survived to 2 weeks of age had died ( 800-900 chicks); most were approximately 2-4 weeks old. Cold, wet, windy weather during the previous week was the most likely contributor to these deaths. A second catastrophic weather event occurred during the night of 2-3 July. A severe thunderstorm with $97-\mathrm{km} / \mathrm{h}$ winds caused the deaths of a large number of chicks; these birds were discovered 5 July 2005. Dead chicks of all ages were found, often in piles, most too decomposed for necropsy. We

Table 2 - Results of tests for Salmonella and botulinum neurotoxin type C conducted on American white pelican chicks and a subsample of those chicks that were collected after WNv was detected in the colonies, Chase Lake, ND; Medicine Lake, MT; Bitter Lake, SD in 2004 and 2005

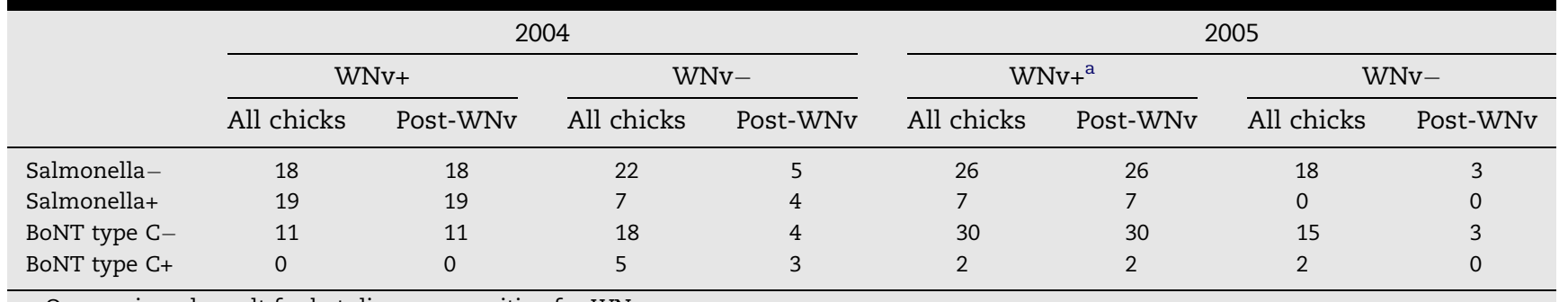

a One equivocal result for botulism was positive for $\mathrm{WNv}$. 


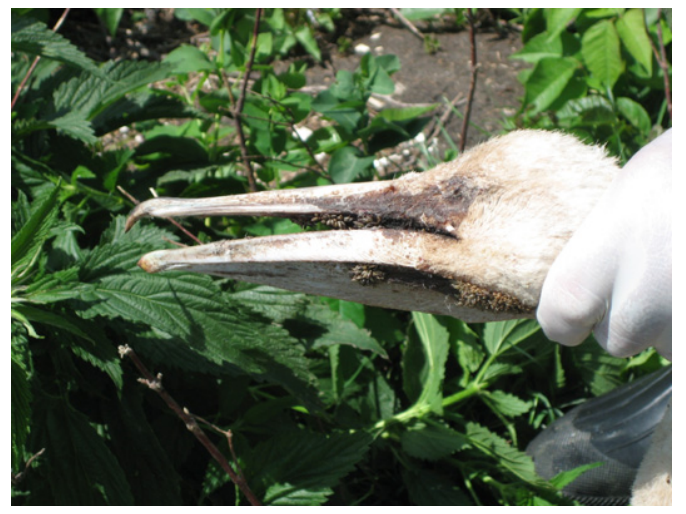

Fig. 5 - American white pelican chick with extreme infestation of pouch lice (Piagetiella peralis) at Chase Lake National Wildlife Refuge in North Dakota. This live chick was blinded by crusting (mixture of blood and louse excrement) around its eyes and lice attached inside the eyelid. Culture of the inner eyelid and tissues around the inner eye resulted in growth of the common bacteria, Proteus.

sent a sample of chicks for disease testing to be sure WNv had not contributed to the death, and all were negative for WNv. We were unable to get an accurate count of the dead because of access restrictions related to weather and rapidly decomposing carcasses, however, by using band data, we estimated approximately $30 \%$ chick mortality.

In 2006, severe weather occurring 8-10 June caused deaths of approximately 400 chicks at Chase Lake and 175 chicks at Medicine Lake. Again, chicks that died were approximately 2-4 weeks old, the vulnerable period of transition between brooding and crèching.

At Chase Lake's south island subcolony, extreme infestations of pouch lice (Piagetiella peralis) were found on numerous chicks on 7 July 2005 (Fig. 5). Pouches of individual birds had thousands of adult and immature lice. Some of the chicks were blinded and immobile because of crusting (mixture of blood and louse excrement; see Wobeser et al., 1974) around their eyes; in some cases, lice attached inside the eyelid (Fig. 5). Culture of the inner eyelid and tissues around the inner eye resulted in growth of the common bacteria, Proteus. Severity of infestations subsided after about 3 weeks. A small portion of chicks died (estimate $<100$ chicks) as a result of the heavy lice infestations. Necropsy results on 10 of the chicks indicated the chicks were not suffering from other diseases.

\subsection{Mosquito monitoring}

The average number of Culex tarsalis captured per trap night was 23.5 in 2004, 56.1 in 2005, and 5.8 in 2006 (Fig. 6). Prevalence of mosquitoes followed the trends in the Palmer Drought Index (Palmer, 1965; Fig. 6), with fewer mosquitoes during drier conditions in 2006. Notably, the positive diagnostic results for WNv occurrence in the pelican chicks followed the seasonal prominence of this mosquito species (Fig. 4).

\section{Discussion}

Before WNv arrived in the region, natural mortality of pelican chicks was low during the late breeding season. Less than $5 \%$ mortality rate for chicks has been commonly reported for the late breeding season in pre-WNv years, including at Medicine Lake and Chase Lake during this study, at Chase Lake in the 1970s (Strait, 1973), and at Marsh Lake in Minnesota (J. DiMatteo, North Dakota State University, pers. commun.) before 2002. Thus, WNv is impacting the chicks that would be expected to survive to fledge. A few years of near or total reproductive failure (e.g., Chase Lake 2004, 2005) may not impact population stability of long-lived species like the American white pelican (Diem and Pugesek, 1994). To date, these catastrophic events have not occurred frequently enough to reduce the size of pelican colonies in the northern plains. On the other hand, if late-season chick mortalities continue indefinitely at the rates observed since WNv arrived in the region, the effects likely will be seen at the population level in the future.

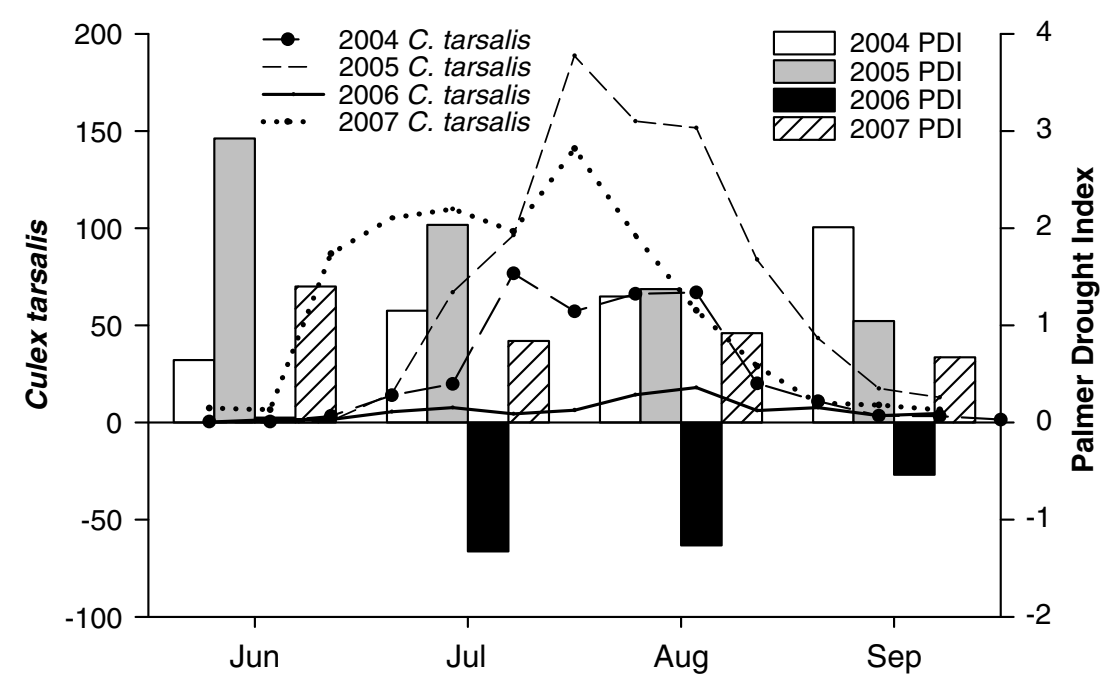

Fig. 6 - Index to abundance of the WNv mosquito vector, Culex tarsalis, and Palmer Drought Index for North Dakota, 20042007. 
This disease has shown little sign of abating at pelican colonies in the northern plains. It is unlikely that the lower rates of chick mortality during the late breeding season in 2006 indicate increased immunity to the disease, but rather reflect low mosquito populations as a result of near drought conditions. This interpretation is supported by the fact that in 2007 mosquito populations and chick mortality rates returned to higher levels (Figs. 3 and 6). Similarly, Walker et al. (2007) reported that greater sage-grouse (Centrocercus urophasianu) have shown little immunity to $\mathrm{WNv}$ and concluded that severity of future outbreaks will be more dependent on vector production than immune response. The loss of productivity at the colonies we monitored, and the concurrent and perhaps similar magnitude of chick mortality at other colonies in the northern plains (e.g., Marsh Lake, MN, J. Wollenberg, Minnesota Department of Natural Resources, pers. commun.; several colonies in Saskatchewan, C. Somers, University of Regina, pers. commun.), suggest that the impact of WNv on pelican populations could be considerable. However, the long-term impacts of this disease on the regional and perhaps continental population level remain unclear because we do not know whether current levels of susceptibility to the virus will persist or if immunity to the virus will develop. We initiated research in 2006 to evaluate whether immunity is conferred through the egg from the mother to the offspring and if immunity is developing in surviving chicks.

Each year, the timing of disease onset closely followed the emergence of the mosquito Culex tarsalis in the region and persisted with the mosquito through the summer. C. tarsalis is one of the most highly efficient vectors of $\mathrm{WNv}$ in North America (Hayes et al., 2005; Turell et al., 2005). The lower mortality rates of pelican chicks in the drought year of 2006, when mosquito numbers were lower, also suggest a connection between $C$. tarsalis and the incidence of WNv in pelican chicks. However, C. tarsalis may not be the only WNv vector for pelicans. In 2006, for example, a mosquito trap placed on one of the Chase Lake islands with nesting pelicans caught no C. tarsalis (G. Johnson, University of Montana, unpublished data). There may be another important, yet undocumented vector of the disease affecting white pelicans, such as soft ticks (Hutcheson et al., 2005; Mumcuoglu et al., 2005), louse flies (Gancz et al., 2004), or biting midges Culicoides sonorensis (Naugle et al., 2004). Pouch lice taken from two chicks in 2005 during necropsy were tested and found positive for WNv. This result was not surprising given that the chicks also tested positive for WNv. We do not know if pouch lice can carry the virus from one chick to another.

Based on the relatively good body condition of chicks that have tested positive for WNv, we believe that once a chick contracts the disease, death comes relatively quickly. Moreover, many of the chicks that succumbed to WNv did not suffer from other diseases; thus, it is likely that healthy chicks are no less vulnerable to $\mathrm{WNv}$ than chicks in poor condition.

Our documentation of the extent and intensity of WNv in this species is especially noteworthy because the disease is not known to cause large-scale mortality events in the pre-fledged young of other free-living avian species. In
North America, WNv has been implicated in population declines of greater sage-grouse (Naugle et al., 2005), American crows (Corvus brachyrhynchos; Yaremych et al., 2004; Caffrey et al., 2005), and breeding birds in general (Koenig et al., 2007; LaDeau et al., 2007). Those studies focused on losses of adults and fledged young, whereas we focused on pelican chicks, showing them to be especially vulnerable to this disease. In contrast, we did not find adult pelicans with WNv at the colonies and there is no evidence that adult pelicans are highly susceptible to the disease (USGS, National Wildlife Health Center Epizootic data base). Among colonial species, pelicans were the first documented to have such high rates of chick mortality attributed to WNv (USGS, National Wildlife Health Center Epizootic data base).

Based on the behavior of the disease in pelican colonies (e.g., how quickly it spreads), we currently are investigating the possibility that there may be bird-to-bird transmission of the virus rather than just mosquito-to-bird transmission. This mode has been documented in captive populations of chickens, crows, and geese (Langevin et al., 2001; McLean et al., 2001; Swayne et al., 2001; Banet-Noach et al., 2003) but not in free-ranging populations of native birds. The pelicans' colonial nature (i.e., living in close quarters, chicks forming crèches) and their feeding behavior (i.e., regurgitation and feeding off the ground) could foster transmission of the virus from bird to bird. We began research in 2006 to better understand mechanisms of WNv transmission among chicks in the colonies.

Other factors affecting pelican reproductive success during our study included severe weather events and predator disturbance. We cannot explain with certainty what led to the departure of all adult pelicans from the Chase Lake colony in 2004; however, we do know that WNv was not a factor. The abandonment of all subcolonies occurred prior to emergence of $C$. tarsalis, the WNv mosquito vector. The evidence we documented and our knowledge of coyote and pelican behavior support the conclusion that coyote activity caused the abandonment of the entire peninsula subcolony in late May. Reported abandonment of colonies because of coyotes in British Columbia (Bunnell et al., 1981), Wyoming (Findholt and Diem, 1988), and South Dakota (S. Comeau-Kingfisher, US Fish and Wildlife Service, pers. commun.) provide further support for our conclusion. We believe the subsequent departures of adult pelicans in early June from the remaining island subcolony and the 300-nest subcolony at Medicine Lake likely were related to the prolonged period of severe weather just prior to their exodus. At 2-3 weeks old, the chicks at these two locations were vulnerable to exposure because they were just beginning to form crèches as the adults discontinued brooding them. While chicks were in this transitional stage, the severe conditions could have caused high chick mortality, resulting in the adult departures. About 800 chicks were found dead at Marsh Lake in western Minnesota (J. Wollenberg, Minnesota Department of Natural Resources, pers. commun.) immediately following the same weather event. During the years of this study, we observed great annual variation in the proportions of chicks that died as a result of severe weather. 
Pouch lice are common parasites of pelicans (Knopf and Evans, 2004), but the 2005 infestation was unusually, although not uniquely, severe (Strait, 1973; Wobeser et al., 1974). It is not known if the chicks were predisposed to lice infestations by weakened condition or if other physiological factors were involved. The hot, humid, and windless microclimate created by thick vegetation that surrounded chicks on the island where infestations were most severe may have contributed to the persistence and abundance of lice on the pelicans. The severe lice infestations in 2005 peaked prior to onset of WNv and subsided about the time WNv deaths were peaking.

In summary, we have documented reduced productivity attributed to weather, predator disturbance, and disease in local populations of white pelicans. Other factors that could influence productivity include human disturbance (Anderson and King, 2005), environmental contaminants, changes in the distribution or availability of food, degradation of breeding and wintering habitats, and interactions with other species (e.g., gulls). However, there is no evidence that these other factors affected any of the colonies we studied. Among the factors identified at our colonies, only predator disturbance is being managed at the local level. It is not clear whether management of WNv (e.g., by controlling disease vectors) is feasible or practical. Paradoxically, colonial nesting of pelicans may provide opportunities to mange the disease that are not available for species with widely dispersed nests. Because pelican chicks are the vulnerable cohort and there are a limited number of large disjunct colonies in which most production occurs, it may be reasonable to focus management on vulnerable colonies that are crucial to overall population viability. If WNv continues to be an additive source of mortality for pelican chicks in the northern plains breeding colonies, this disease has the potential to severely impact the entire population. Understanding the repercussions of $\mathrm{WNv}$ for the American white pelican population requires a coordinated monitoring strategy that is both long-term and range-wide.

\section{Acknowledgments}

Special thanks go to M.J. Assenmacher, A.J. Bartos, J. Feine, R.D. Flagen, B. Haase, N.B. Larson, and R.O. Woodward for their assistance with field data collection. We are indebted to US Fish and Wildlife Service cooperators at Chase Lake, Waubay, and Medicine Lake National Wildlife Refuges, especially N. Buskness, M. Erickson, L. Hubers, and E. Madden for field assistance, logistic support, and advice. We thank the many volunteers who helped with tasks such as banding and monitoring. We are grateful to J. DiMatteo and M. Restani for insightful discussions and access to information on banded birds. A.J. Bartos, D.A. Buhl, L.D. Igl, D.E. Naugle, R. Primack, and an anonymous reviewer offered helpful comments on earlier drafts of this manuscript. We thank the North Dakota Department of Health and G. Johnson and K. Hale, Montana State University, for assistance monitoring mosquitoes. This work was funded by the US Geological Survey's Northern Prairie Wildlife Research Center and National Wildlife Health Center; the North Dakota Game and Fish Department; the South Dakota Game, Fish and Parks Department; and the US Fish and Wildlife Service.

\section{R E F E R E N C E S}

Anderson, D.W., King, D.T., 2005. Introduction: biology and conservation of the American white pelican. Waterbirds 28, 18 (Special Publication).

Andrews, E.J., Bennett, B.T., Clark, J.D., Houpt, K.A., Pascoe, P.J., Robinson, G.W., Boyce, J.R., 1993. Report of the AVMA panel on euthanasia. Journal of the American Veterinary Medicine Association 202, 230-249.

Banet-Noach, C., Simanov, L., Malkinson, M., 2003. Direct (nonvector) transmission of West Nile virus in geese. Avian Pathology 32, 489-494.

Beaty, B.J., Calisher, C.H., Shope, R.E., 1989. Arboviruses. In: Schmid, N.J., Emmons, R.W. (Eds.), Diagnostic Procedures for Viral Rickettsial and Chalamydial Infections, 6th Ed. American Public Health Association, Washington, DC, USA.

Blitvich, B.J., Marlenee, N.L., Hall, R.A., Calisher, C.H., Bowen, R.A., Roehrig, J.T., Komar, N., Langevin, S.A., Beaty, B.J., 2003. Epitope-blocking enzyme-linked immunosorbent assays for the detection of serum antibodies to West Nile virus in multiple avian species. Journal of Clinical Microbiology 41, 1041-1047.

Bluemle, J.P., 1991. The Face of North Dakota. Educational Series 21. North Dakota Geological Survey, Bismarck, North Dakota, USA.

Bunnell, F.L., Dunbar, D., Koza, L., Ryder, G., 1981. Effects of disturbance on the productivity and numbers of white pelicans in British Columbia-observations and models. Colonial Waterbirds 4, 2-11.

Caffrey, C., Smith, S.C.R., Weston, T.J., 2005. West Nile virus devastates an American crow population. Condor 107, 128132.

Daszak, P., Cunningham, A.A., Hyatt, A.D., 2000. Emerging infectious diseases of wildlife-threats to biodiversity and human health. Science 287, 443-449.

De Smedt, J., Bolderdijk, R., 1987. Dynamics of Salmonella isolation with modified semi-solid Rappaport-Vassiliadis medium. Journal of Food Protection 50, 658-661.

Diem, K.L., Pugesek, B.H., 1994. American white pelicans at the Molly islands, in Yellowstone National Park: twenty-two years of boom-and-bust breeding, 1966-1987. Colonial Waterbirds 17, 130-145.

Docherty, D.E., Long, R.R., Griffin, K., Saito, E.K., 2004. Corvidae feather pulp and West Nile virus detection. Emerging Infectious Diseases 10, 907-909.

Evans, R.M., 1984. Some causal and functional correlates of crèching in young white pelicans. Canadian Journal of Zoology 62, 814-819.

Findholt, S.L., Diem, K.L., 1988. Status and distribution of American white pelican nesting colonies in Wyoming: an update. Great Basin Naturalist 48, 285-289.

Gancz, A.Y., Barker, I.K., Lindsay, R., Dibernardo, A., Mckeever, K., Hunter, B., 2004. West Nile virus outbreak in North American owls, Ontario, 2002. Emerging Infectious Diseases 10, 21352142.

Gaunt, A.S., Oring, L.W. (Eds.), 1997. Guidelines to the Use of Wild Birds in Research. The Ornithological Council, Washington, DC, USA.

Ginsberg, J., 2003. The new polio? New Scientist 178, 41-43.

Hayes, E.B., Komar, N., Nasci, R.S., Montgomery, S.P., O'Leary, D.R., Campbell, G.L., 2005. Epidemiology and transmission dynamics of West Nile virus disease. Emerging Infectious Diseases 11, 1167-1173.

Hutcheson, H.J., Gorham, C.H., Machain-Williams, C., LoroñoPino, M.A., James, A.M., Marlenee, N.L., Winn, B., Beaty, B.J., Blair, C.D., 2005. Experimental transmission of West Nile virus (Flaviviridae: Flavivirus) by Carios capensis ticks 
from North America. Vector-Borne and Zoonotic Diseases 5, 293-295.

King, D.T., Anderson, D.W., 2005. Recent population status of the American white pelican: a continental perspective. Waterbirds 28, 48-54 (Special Publication).

Knopf, F.L., Evans, R.M., 2004. American white pelican (Pelecanus erythrorhynchos). In: Poole, A. (Ed.), The Birds of North America Online. Cornell Laboratory of Ornithology, Ithaca. Retrieved from The Birds of North American Online database, <http:// bna.birds.cornell.edu/BNA/account/American_White_ Pelican/> (17 September 2007).

Koenig, W.D., Marcus, L., Scott, T.W., Dickinson, J.L., 2007. West Nile virus and California breeding bird declines. EcoHealth 4, 18-24.

Kuiken, T., Leighton, F.A., Wobeser, G., Wagner, B., 1999. Causes of morbidity and mortality and their effect on reproductive success in double-crested cormorants from Saskatchewan. Journal of Wildlife Diseases 35, 331-346.

LaDeau, S.L., Kilpatrick, A.M., Marra, P.P., 2007. West Nile virus emergence and large-scale declines of North American bird populations. Nature 447, 710-713.

Lanciotti, R., Kerst, A., Nasci, R., Godsey, M., Mitchell, C., Savage, H., Komar, N., Panella, N.A., Allen, B.C., Volpe, K.E., Davis, B.S., Roehrig, J.T., 2000. Rapid detection of West Nile virus from human clinical specimens, field-collected mosquitoes, and avian samples by a TaqMan Reverse Transcriptase-PCR assay. Journal of Clinical Microbiology 38, 4066-4071.

Langevin, S.A., Bunning, M., Davis, B., Komar, N., 2001. Experimental infection of chickens as candidate sentinels for West Nile virus. Emerging Infectious Diseases 7, 726-729.

Lingle, G.R., 1977. Food habits and sexing-aging criteria of the white pelican at Chase Lake National Wildlife Refuge, North Dakota. MS Thesis. Michigan Technological University, Houghton, USA.

Madden, E.M., Restani, M., 2005. History and breeding ecology of the American white pelican at Medicine Lake National Wildlife Refuge, Montana. Waterbirds 28, 23-26 (Special Publication).

Marra, P.P., Griffing, S., Caffrey, C., Kilpatrick, A.M., McLean, R., Brand, C., Saito, E., Dupuis, A.P., Kramer, L., Novak, R., 2004. West Nile virus and wildlife. BioScience 54, 393-402.

Mallinson, E.T., Miller, R.G., DeRezende, C.E., Ferris, K.E., deGraftHanson, J., Joseph, S.W., 2000. Improved plating media for the detection of Salmonella species with typical and atypical hydrogen sulfide production. Journal of Veterinary Diagnostic Investigation 12 , 83-87.

McLean, R.G., Ubico, S.R., Docherty, D.E., Hansen, W.R., Sileo, L., McNamara, T.W., 2001. West Nile virus transmission and ecology in birds. Annals of the New York Academy of Sciences 951, 54-57.

Mumcuoglu, K.Y., Banet-Noach, C., Malkinson, M., Shalom, U., Galun, R., 2005. Argasid ticks as possible vectors of West Nile virus in Israel. Vector-Borne and Zoonotic Diseases 5, 65-71.

Miller, R.G., Tate, C.R., Mallinson, E.T., Scherrer, J.A., 1991. XyloseLysine-Tergitol 4: an improved selective agar medium for the isolation of Salmonella. Poultry Science 70, 2429-2432.
Naugle, D.E., Aldridge, C.L., Walker, B.L., Cornish, T.E., Moynahan, B.J., Holloran, M.J., Brown, K., Johnson, G.D., Schmidtmann, E.T., Mayer, R.T., Kato, C.Y., Matchett, M.R., Christiansen, T.J., Cook, W.E., Creekmore, T., Falise, R.D., Rinkes, E.T., Boyce, M.S. 2004. West Nile virus: pending crisis for greater sage-grouse. Ecology Letters 7, 704-713.

Naugle, D.E., Aldridge, C.L., Walker, B.L., Doherty, K.E., Matchett, M.R., McIntosh, J., Cornish, T.E., Boyce, M.S., 2005. West Nile virus and sage grouse: what more have we learned? Wildlife Society Bulletin 33, 616-623.

Palmer, W.C., 1965. Meteorological drought. Research Paper 45. US Department of Commerce, Weather Bureau, Washington, DC, USA, p. 58.

Reinert, W.C., 1989. The New Jersey light trap: an old standard for most mosquito control programs. In: Proceedings of the Seventy-Sixth Annual Meeting of the New Jersey Mosquito Control Association. <http://www.rci.rutgers.edu/ insects/ njtrap.htm> (17 September 2007), pp. 17-25.

Rocke, T.E., Smith, S.R., Nashold, S.W., 1998. Preliminary evaluation of a simple in vitro test for the diagnosis of type $\mathrm{C}$ botulism in wild birds. Journal of Wildlife Diseases 34, 744-751.

SAS Institute Inc., 2004. SAS OnlineDoc ${ }^{\circledR}$ 9.1.2. SAS Institute Inc., Cary, North Carolina.

Shimizu, T., Kondo, H., 1987. Techniques for assaying C1, C2, and D Botulinal Antitoxins. In: Ecklund, M.W., Dowel, V.R., (Eds.), Avian Botulism: An International Perspective. Charles C. Thomas, Springfield, Illinois, pp. 363-369.

Sovada, M.A., King, D.T., Ericson, M., Gray, C., 2005. Historic and current status of breeding American white pelicans at Chase Lake National Wildlife Refuge, North Dakota. Waterbirds 28, 27-34 (Special Publication).

Strait, L.E., 1973. Population dynamics of a white pelican population, Chase Lake National Wildlife Refuge, North Dakota. M.S. Thesis. Michigan Technological University, Houghton, USA.

Swayne, D.E., Beck, J.R., Smith, C.S., Shieh, W.J., Zaki, S.R., 2001. Fatal encephalitis and myocarditis in young domestic geese (Anser anser domesticus) caused by West Nile virus. Emerging Infectious Diseases 7, 751-753.

Turell, M.J., Dohm, D.J., Sardelis, M.R., O'Guinn, M.L., Andreadis, T.G., Blow, J.A., 2005. An update on the potential of North American mosquitoes (Diptera: Culicidae) to transmit West Nile virus. Journal of Medical Entomology 42, 57-62.

van Riper, C., van Riper III, S.G., Goff, M.L., Laird, M., 1986. The epizootiology and ecological significance of malaria in Hawaiian land birds. Ecological Monographs 56, 327-344.

Walker, B.L., Naugle, D.E., Doherty, K.E., Cornish, T.E., 2007. West Nile virus and greater sage-grouse: estimating infection rate in a wild bird population. Avian Diseases 51, 691-696.

Wobeser, G., Johnson, G.R., Acompanado, G., 1974. Stomatitis in a juvenile white pelican due to Piagetiella peralis (Mallophaga: monopondidae). Journal of Wildlife Diseases 10, 135-138.

Yaremych, S.A., Warner, R.E., Mankin, P.C., Brawn, J.D., Raim, A., Novak, R., 2004. West Nile virus and high death rate in American crows. Emerging Infectious Diseases 10, 709-711. 